\title{
Jesus and politics in contemporary scholarship
}

\author{
Marcus J Borg \\ Oregon State University \\ Visiting Professor: University of Pretoria
}

\begin{abstract}
Until recently, and for a variety of reasons, most historical Jesus scholarship has typically seen Jesus as essentially non-political. Recently, this has begun to change, to a large extent because of the fuller description of the social world of Jesus made possible by the use of interdisciplinary models and insights. Seen within the context of a social world described as a peasant, patriarchal and purity society, many of the Jesus traditions reflect both a sharp critique of society and advocacy of an alternative social vision. Jesus' action in the temple (including $E P$ Sanders view of it) is treated as a case study of the difference made by an interdisciplinary understanding of the social context of Jesus' public activity.
\end{abstract}

\section{INTRODUCTION}

One of the most notable features of contemporary Jesus scholarship is a reopening of the question of Jesus and politics. Significant voices in North American scholarship, in what could be an emerging majority position, are affirming that there was a sociopolitical dimension to the message and activity of Jesus.

This is a new development, even though the claim that Jesus was political goes back to the birth of the discipline over two hundred years ago. In a work commonly seen as the beginning of the quest for the historical Jesus, Hermann Samuel Reimarus argued that Jesus' message about the Kingdom of God referred to a this-worldly kingdom which would involve liberation from Rome, and that Jesus' death resulted from his naive expectation that he could stir up a successful revolt (see Reimarus 1970). Yet most often, scholars in the two centuries since have denied that Jesus was political ${ }^{1}$.

Why has this changed? The major reason is one of the central characteristics of the contemporary renaissance: the entry into the discipline of interdisciplinary models and perspectives. These provide new angles of vision for seeing the social world of Jesus. Social world is context, and these perspectives give us a fuller picture of the context within which the Jesus tradition receives its historical meaning. I will describe three of these perspectives, what they enable us to see about the social world of first-century Jewish Palestine, and their effects as lenses through which to see the Jesus tradition. 


\section{THE IMPORTANCE OF DEFINITION}

There is both a narrow and broad definition of politics, and whether one sees Jesus as political is greatly affected by one's definition. The narrow definition associates politics with 'government': to be political is to seek to affect governmental policy, or to gain a position of governmental power, or to attempt to overthrow the government. The broader definition of politics builds on the semantic associations of its Greek root

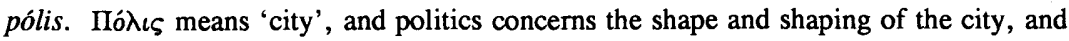
by extension the shape and shaping of a society's life.

If politics is used in the narrow sense, then Jesus was basically non-political. A few scholars since Reimarus have argued that Jesus sought a change in government by inciting a political rebellion against Rome, but their arguments have not persuaded many. Moreover, it seems evident that Jesus did not seek a position of governmental power or to reform governmental policy.

Yet, as I shall argue, Jesus both challenged the existing social order and advocated an alternative. That challenge involved social criticism, an alternative social vision, and the embodiment of that vision in the life of a community. This is 'political' in the broad sense of the word. Indeed, in this broader sense, much of the biblical tradition is political. Ancient Israel's originating event involved liberation from the lordship of Pharaoh and creation of the alternative community of Moses. Much of the legal portion of the Torah concerns the structuring of community life, and not just individual virtue. The political character of the tradition continues in the second major division of the Hebrew Bible, the prophets. From King David onward through the time of the monarchies, a period of about four hundred years, the social prophets of Israel indicted the ruling elites (political, economic, and religious) in the name of an alternative social vision which they affirmed to come from God.

It is in this broader sense of the word 'politics' that contemporary scholarship is increasingly affirming a socio-political dimension to Jesus. Before turning to that, it will be illuminating briefly to examine some of the reasons why Jesus has commonly been seen as non-political by both popular Christianity and academic scholarship.

\section{THE EXCLUSION OF POLITICS}

There are at least four major reasons for the denial of politics to Jesus. The first is because Jesus scholars have most often used the narrow definition of politics. Both proponents and critics of seeing Jesus as an advocate of the cause of Jewish liberation from Rome (what used to be called 'the Zealot hypothesis' 2 ) have tended to equate being 'political' in first-century Palestine with anti-Roman revolutionary activity. Denying that Jesus was this, most scholars have concluded that Jesus was therefore non-political. It is striking how often one runs into this argument in the history of scholarship (Borg 1984:5-8). 
Even more pervasive as a reason for the exclusion of politics has been the Gestalt of Jesus as an eschatological figure. The logic is straightforward: because Jesus expected the last judgment and the 'end' of this world soon, or alternatively because he expected the transformation of this world through a supernatural act of God, he was not interested in social or political questions. What did they matter? Why be concerned to change the world if in its present form it was soon to end? From Albert Schweitzer at the beginning of this century through Rudolf Bultmann and Gunther Bornkamm and (in some quarters) into the present, this has been a frequent refrain of scholarship ${ }^{3}$.

A third reason is the individualistic orientation of much of modern Jesus scholarship. It has taken several forms. Within the framework of traditional Christian piety, Jesus and the New Testament are seen as concerned with the eternal religious questions of the individual and his or her relationship to God and the neighbor, not with the specific social and political issues of a particular time and place. This way of seeing Jesus was especially common in nineteenth century scholarship, though its effects linger into the present. In this century, existentialist interpretation of Jesus' eschatology has most commonly radically internalized and individualized his message. The individualistic reading of the tradition continues in our time in the picture of Jesus as a Hellenistic-type Cynic sage who spoke of a life-style for individuals, not for a community.

A fourth reason is the social location of Jesus scholarship. Since its beginnings in the Enlightenment, most of it has been done by northern Euro-American academics who have generally been white, male, and middle-class. Moreover, until recently, most of our academic positions have been in institutions related to the church.

Perhaps more than anything else, that social location affects how and what we see. It generates the perspectives through which we see the world, including the world behind the texts, and functions as both lens and blinders. Five factors are especially important:

* The academy tends to be an individualistic milieu, and accounts in part for the individualistic orientation just described.

* The churchly social location of much of scholarship has led to seeing the texts through Christian (or sometimes 'anti-Christian') lenses: the focus is on the relationship of the texts to Christian teachings (beliefs and ethics) rather than on their relationship to the social environment out of which they came.

* Within the framework of the modern separation of religion and politics, scholars have often concentrated on the 'religious' meaning of texts, as if religion were separable from other matters in the first century. 
* The middle-class status of most academics has not been conducive to seeing a socio-political dimension in the Jesus traditions, just as the social location of much of the church during the centuries of Christendom made it unlikely that priests and preachers would find Jesus' message to be politically subversive. The social location of scholarship means that we often miss things in the text which the experience of poverty, marginality, patriarchy or oppression might have led us to see.

* Finally, unless we make special efforts to compensate for it, our seeing of texts is unconsciously shaped by our experience of the world which we know, namely post-Enlightenment modern industrial society with its middle class and emphasis upon individualism 4 .

\section{SEEING FROM NEW PERSPECTIVES}

To some degree, the social location of scholarship remains much the same. The majority of us are still middle-class white male northern Euro-Americans in academic institutions. What then accounts for a more political reading of the Jesus traditions? The primary reason is the emergence of new perspectives from which to see the traditions. The change is not because we suddenly have new data; rather, for a number of reasons, familiar data are being seen in new ways.

New voices have entered the discipline, especially feminist and liberationist voices. The 'view from below' provides an angle of vision on the texts quite different from the view 'from the middle' or the 'view from the top'.

Many of us (probably a majority) now teach in secular or secularized universities and colleges. The change in institutional setting means that the questions brought to the texts are no longer shaped primarily by a Christian agenda. The focus has shifted to the relationship of the texts to their original historical setting, and/or to their relationship to other disciplines within a more pluralistic academy.

The final reason flows out of the previous one: the emergence of interdisciplinary and cross-cultural perspectives and models for seeing the traditions about Jesus ${ }^{5}$. These new perspectives and models make it possible to some extent to step outside our own social world by providing vantage points which enable us to enter imaginatively into the very different social world of first-century Jewish Palestine and to see meanings in the Jesus tradition we otherwise would not see.

I want to illustrate this claim by describing the perspectives generated by three social models. Each highlights a major characteristic of Jesus' social world and thereby provides a context within which to place many of the most central themes of his message and activity. Together, they enable us to see that Jesus was a socio-political critic as well as an advocate of an alternative social vision - in short, that he was 'political' in the broad sense of the word. 


\section{PEASANT SOCIETY AND POLITICS IN FIRST-CENTURY PALESTINE}

The first perspective providing a new way of seeing both the social world of firstcentury Palestine and the meaning of words and actions in that context is the awareness that it was a peasant society. To say that it was a peasant society does not mean simply that there were a lot of peasants (though that is true). Rather, it is shorthand for a particular type of society, namely 'pre-industrial agrarian society', one of five types of society identified by Gerhard Lenski $(1966)^{6}$.

According to Lenski, peasant societies are different not only from modern industrial societies but also from three other pre-modern types of society: hunting and gathering, simple horticultural, and advanced horticultural societies. The difference between peasant societies and horticultural societies is in part technological. The digging stick and hoe were replaced by the plow, increasing both the scale and efficiency of agriculture.

Even more so, the difference between peasant societies and earlier horticultural societies is socio-economic organization: the emergence of centralized forms of government. Cities (and not simply towns) began to develop, made possible by greater agricultural production, to be followed by city-states, nations, and eventually empires.

These more centralized forms of social organization were dominated by ruling elites who generally lived in cities or towns. The politically and economically dominant urban elites no longer worked the land, even though (as we shall see) they controlled much of the land. Thus in these societies, there were essentially two social classes: urban elites, and rural peasants. Between these two classes there was a huge gulf. Indeed, 'marked social inequality' was the single most striking trait of preindustrial agrarian societies (Lenski 1966:210).

This inequality was above all one of wealth. Where did the urban elites get their wealth? They did not manufacture anything or produce anything. In these societies, there was no significant generation of wealth through industry; manufacturing was small-scale and done by hand. Rather, in such societies the primary source of wealth was agriculture: land and the people who worked the land.

Thus, in a sentence, the elites got their wealth from the peasants. They did so through a 'tributary mode of production' by means of which they extracted wealth from peasants in two ways 7 . The first was land rental. Through the process of land consolidation, the elites over time owned more and more of the land. Peasants who were small landholders easily acquired debt and often lost their land to the elites to whom they were indebted. Ownership of agricultural land generated income from land rent (paid in cash or kind) and the subsistence employment of agricultural workers ${ }^{8}$. 
The second source of income was taxation, which was primarily on agricultural production. Through these two means, wealth flowed from the countryside to the city, from rural peasants to urban elites. Estimates vary and differ to some degree from society to society, but generally about two-thirds of the wealth generated by agriculture ended up in the hands of the urban elites 9 . The remaining one-third was left for the other ninety per cent of the population, the rural peasants who were, of course, the primary producers of wealth ${ }^{10}$.

To fill out the model, Lenski subdivides the primary twofold class division into nine more specific classes. The upper five comprised the urban elites. The first two of these were the ruler himself, plus the governing class (high officials and traditional aristocracies). Together, they were one to two per cent of the population and generally received one half of the wealth generated by agricultural production. Third, retainers were essentially a service class to the elites, in effect, their employees. The retainer class included soldiers, bureaucrats, scribes, tax collectors, et cetera. Fourth and fifth were a merchant class and (in many societies) a priestly class. These three groups typically comprised about eight per cent of the population, and received about one-sixth of the society's income. The four lower classes (ninety per cent of the population) were peasants proper (agriculturalists), artisans, unclean and degraded classes (despised or downgraded occupations), and expendables (outlaws, beggars, etc.)

The above is not intended as a description of first-century Jewish Palestine in particular. Rather, in broad strokes, it describes most pre-modern agrarian societies with centralized forms of government. Indeed, this type of society characterized ancient Israel throughout much of her history, beginning with the emergence of the monarchy around $1000 \mathrm{BCE}$. Seeing this has great illuminating power. I can recall how it transformed my understanding of the classical prophets of ancient Israel. When I was in seminary and graduate school some twenty-five years ago, I was struck by the prophets' passion for social justice and their warnings of impending historical destruction because of injustice. Then and through the first half of my teaching career, I also took it for granted (as most scholars did, I think) thai their indictments and warnings were directed at Israel 'as a whole': Israel had become unjust and corrupt.

Then, some ten to fifteen years ago as models of peasant societies began to have an effect on biblical scholarship, the awareness that ancient Israel was a two-class society divided between oppressive urban elites and exploited rural peasants generated a very different perception of the prophetic message. Their indictments were directed not at Israel, but at the elites in particular. It was the elites (and not the population as a whole) who were responsible for the injustice and oppression which the prophets attacked. 
The basic form of this type of society continued into the time of Jesus ${ }^{11}$. In Galilee, the elites were large landholders, the Herodian court, and retainers attached to both groups. In Judea, the elites were concentrated in Jerusalem: the high priestly families and the traditional aristocracy, and, of course, their retainers. As in peasant societies generally, wealth flowed to these elites through ownership of land and taxation.

Though some peasants still owned small pieces of land, much of it was owned by absentee landlords living in cities and towns who typically collected from one-fourth to one-third of agricultural production as 'rent ${ }^{12}$ '. Taxes on the agricultural production of peasants were paid to both civil and religious authorities. Though we do not have precise information about tax rates under Herod the Great, estimates place it between ten and twenty per cent ${ }^{13}$, a range which his sons presumably continued. When Judea came under direct Roman rule in $6 \mathrm{CE}$, the Roman crop tax was apparently twelve and one-half per cent (Sanders 1992:167).

There was also taxation by religious authorities, namely the tithes of the Torah, which amounted to taxes on agricultural produce. As understood in the first century, these included each year a first tithe and a second tithe, and, apparently, a third tithe every third year ${ }^{14}$. Though estimates can only be approximate, the combination of taxes and tithes probably amounted to thirty to thirty-five per cent of agricultural production 15 . Added to the one-fourth to one-third paid in land rent by peasants not owning their own land, the portion of agricultural income flowing from peasants to the urban elites may have been as high as sixty percent to two-thirds ${ }^{16}$. Like other peasant societies, first-century Palestine was thus marked by pervasive economic exploitation and oppression ${ }^{17}$.

The recognition that the social world of Jesus was a peasant society with a two class system and tributary mode of production provides a social context which illuminates many of the traditions about Jesus. Because it is not possible within the limits of this essay to provide a detailed exegesis or even a comprehensive listing of all relevant passages, I will cite only a few exampies in order to illustrate the difference this fresh perspective on the social world of Jesus makes.

It casts Jesus' sayings about the poor and the rich, poverty and wealth, in a different light. 'The poor' (to whom the 'good news' comes, and who are pronounced 'blessed') are the economically oppressed class of a peasant society, just as the rich (against whom woes are spoken) are the wealthy urban elites. Poverty and wealth cease to be abstractions or metaphors. They also cease to be primarily qualities of individuals. Wealth was not the result of being an ambitious hard-working individual striving to advance in the world, but the product of being part of an oppressive social class which extracted its wealth from peasants; and poverty was not the result of failing to make use of one's opportunities. 
Consideration of a particular saying illustrates the difference in meaning generated by setting it in the social world of a peasant society: No one can serve two masters; for a slave will either hate the one and love the other, or be devoted to the one and despise

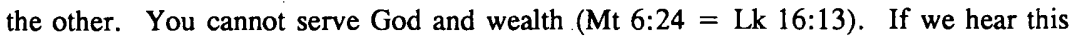
saying within the context of our social location - namely, the kind of social world most of us in the nodern industrialized world know, in which there is a large middle class and considerable possibility of upward mobility - then we are likely to hear it as addressed to individuals faced with the choice of whether to serve God or wealth. Should I pursue affluence in my life, or the service of God? But such a choice did not exist for peasants living in the highly stratified social world of first century Palestine. The statement is not advice directed to the undecided and deciding individual, but an indictment of a social class, the elites (you cannot be wealthy and serve God), even as it also hints at a way of life in which wealth is irrelevant. If we hear it only within our social world, we miss its social meaning in Jesus' social world.

There are many other sayings which are illuminated by the peasant society model. About the scribes, who were retainers of the elites, Jesus said: Beware of the scribes, who like to walk around in long robes, and to be greeted with respect in the marketplaces, and to have the best seats in the synagogues and places of honor at banquets! They devour widows' houses and for the sake of appearance say long prayers. They will receive the greater condemnation ${ }^{18}$. The reference to those who 'devour widows' houses' apparently refers to a legal proceeding, undertaken by scribes as retainers of the elites, whereby homes were expropriated because of debt.

Jesus' threats against Jerusalem (which are quite well grounded in the tradition) are cast in a new light. It is not Jerusalem as the center or symbol of Judaism which is indicted, but Jerusalem as the home of the ruling elites.

The perspective provided by peasant society awareness also enables us to see more clearly where the responsibility for Jesus' death belongs. Given the popular Christian understanding of 'the Jews' as having rejected Jesus, this is a perception of great importance for Jewish-Christian relations. The most likely scenario of Jesus' arrest, condemnation and execution is that it involved cooperation between the Roman governor and the inner circle of the Jerusalem elite, namely the high priest and what has been called his 'privy council19'. In the eyes of the elites, Jesus was a popular leader operating outside of established authority who had attracted a following. Such persons aroused suspicion (and often worse) among those concerned with maintaining the present order. The elites were not only accountable to Rome but also had their own self-interested reasons for preserving the existing order of a peasant society which benefitted them so greatly. Thus it was not 'the Jews' or 'the Jewish people' who 
rejected Jesus. Rather, it was a narrow circle of the Jewish ruling elite who, rather than representing 'the Jews', are more accurately seen as oppressors of the vast majority of the Jewish population of Palestine at the time of Jesus.

To conclude this section, the perspective provided by understanding the dynamics of a peasant society suggests that, whatever else needs to be said about Jesus, he was a social prophet ${ }^{20}$. Indeed, when we realize that the social dynamics which operated in the time of the classical prophets of ancient Israel also operated in the time of Jesus, it is clear that he, like them, indicted the elites and championed the cause of an exploited peasantry 21 . I do not think that he sought to lead a peasant revolt, or that his following can be described simply as a peasant movement. Nevertheless, and minimally, it is clear that he engaged in radical social criticism of the elites of his day. And, given what else can be known about him, social critique was accompanied by an alternative social vision.

\section{PATRIARCHAL SOCIETY AND POLITICS IN PALESTINE}

A second perspective for seeing the politics of Jesus is provided by awareness of the social dynamics of patriarchal societies, brought into biblical scholarship mostly by feminist scholars. Two terms, androcentrism and patriarchy, require definition. Androcentrism refers to a way of seeing, namely seeing from a male point of view. Patriarchy refers to a way of structuring society with two characteristics: it is hierarchical, and male-dominated (Schüssler Fiorenza 1983:29).

Jesus and the early Christian movement lived in a tradition and social world that generally was both. Written texts (including the sacred traditions of Judaism) were almost always produced by males and reflected a male way of seeing the world. A classic example is the book of Proverbs. Though there are many sayings about difficult or fretful wives, there are no sayings about difficult husbands. And though there is an adoring portrait of the ideal wife, there is no portrait of the ideal husband. The explanation is obvious: the book of Proverbs was written by men for other men. So also with the tradition as a whole: male images of deity are dominant, laws are written from a male point of view, and males are assigned all of the official religious positions.

Patriarchy was as omnipresent as androcentrism ${ }^{22}$. Hierarchies with males at the top were the normative forms of social organization (political, religious and familial), both within Palestine and throughout the Roman empire. To put that only slightly differently, the peasant society with its urban ruling elites was also a patriarchal society. The ruler was typically male. Below him were high government and/or priestly officials (male) and the male heads of the traditional aristocratic families. Together, they ruled over all other men, as well as all women and children. 
The patriarchal structure of the society was mirrored in the family. The patriarchal family was a microcosm of society as a whole. People lived in extended patriarchal families, in which the head male was the authority figure. All others were ultimately subject to him. Females were always embedded in some male: father, brother, husband, son. Moreover, it is important to underline how central the family was in that world compared to the modern world. It was the primary unit of economic production and security, as well as the primary center of identity and loyalty.

Together, androcentrism and patriarchy pervasively affected how women were seen and their roles in society. Texts, laws, and customs reflected how women looked through the eyes of men, including both male perceptions as well as projections. Male concerns about honor and shame, as well as anxiety about the legitimacy of heirs, shaped codes governing female sexual behavior ${ }^{23}$. Women were radically separated from men in most arenas of life $\mathrm{e}^{24}$. Respectable women were veiled in public, as they still are today in traditional parts of the Middle East. Access to religious institutions and traditions was limited. In the temple, they were restricted to the court of the women, which was further from the center - the holy of holies - than the court of the men. They were not to be taught the Torah, allegedly because they were not very bright and might be a source of temptation to a male teacher, but perhaps because the ability to interpret Torah was a form of power ${ }^{25}$.

Setting the traditions about Jesus in the context of a social world structured by patriarchy sheds light on a number of texts. All of the stories of Jesus' relationships to women involve ignoring or subverting the structures of patriarchy. The role of women in the early years of the Christian movement (and most likely already in his lifetime) is extraordinary in a patriarchal world. Behind it or undergirding it is a very different vision of social relationships.

Among the texts illuminated by this perspective are the familiar even if also difficult sayings about family. They are generally negative; Jesus was no champion of family values. People are invited to leave their families, indeed to hate father and mother. Christians (scholars as well as ordinary folk) have often been perplexed by the negative attitude toward family and have sought ways of reconciling family life with taking Jesus seriously, most commonly by suggesting that Jesus basically meant that God must come first, and family second. But such an approach abstracts the family sayings from their social context. Originally, they were directed not at 'the family' in general, but at the patriarchal family in particular. The invitation was to break with the patriarchal family - an oppressive hierarchical structure mirroring the society as a whole. 
Patriarchy as social context illuminates two other sayings related to family. To the woman who declared the mother of Jesus to be 'blessed' because of the remarkable character of her son, Jesus said, 'Blessed rather are those who hear the word of God and obey it' (Lk 11:27-28). Without the social context of a patriarchal society, Jesus' response sounds a bit opportunistic and perhaps even insensitive, as if he is simply using the woman's adoring exclamation as an occasion for telling the crowd what is really important. Within the context of a patriarchal society, however, it is a denial that identity for a woman comes from her embeddedness in a male. Rather, there is a source of identity outside of the structures of patriarchy, which thereby also subverts those structures.

Patriarchy as social context also provides a persuasive framework for understanding Matthew 23:9: 'And call no one your father on earth, for you have one Father the one in heaven' (see Schüssler Fiorenza 1983:149-151). Abstracted from its context, it seems to have to do with 'titles' and correct speech. In the context of a society structured around the patriarchal family, however, its meaning is clear, and basically identical to the anti-family sayings: a subversion of patriarchy. Indeed, it is a fascinating use of a male image of God as a way of subverting a male-dominated social order: just as the lordship of God means one is to have no other lords, so the fatherhood of God means one is to have no other fathers.

\section{PURITY SOCIETY AND POLITICS IN FIRST-CENTURY PALESTINE}

A third perspective is provided by studies of purity societies. This is the vantage point which my own work on the politics of Jesus has emphasized: the realization that firstcentury Jewish Palestine was a purity society enables us to see the socio-political significance of sayings and actions connected to purity issues. Because I have exposited this at length elsewhere, here I will highlight what is most central in summary fashion and then make some fresh connections ${ }^{26}$.

Of first importance is the awareness of what a purity society is 27 . Found in many times and places, such societies are explicitly organized around the polarities of pure and impure, clean and unclean. Pure and impure apply to persons, behaviors, places, things, times, and social groups. Applying to persons and social groups, pure and impure may be the product of birth (as in hereditary caste systems), behavior (actions which render one impure), social position (often including occupation), or physical condition (whole versus not whole). The contrasts of pure and impure establish a spectrum ranging from most pure through degrees of purity to marginalized to the radically impure (who often are 'untouchables' or 'outcasts'). The social boundaries generated by the polarities and gradations of pure and impure are typically sharp and strong. 
In purity societies, purity and purity laws have a significance much different from what they mean in the modern Western world. For us, purity is an individual quality, whether of a product (as when something is advertised as 'one hundred per cent pure'), or of a person (an especially innocent or devout individual), or of thoughts (pure and impure thoughts, often connected to sexuality). Purity laws within the religious life are generally viewed by us as relatively unimportant, certainly of less value than 'moral' or 'ethical' teachings. We see them as something only a particularly pious or overly meticulous individual might be much concerned about. Thus, to a large extent, for us purity has been trivialized, individualized, and internalized.

This way of seeing purity has affected the way scholars have seen texts pertaining to purity. It is instructive to read through commentaries on the gospels written more than twenty or thirty years ago to see how they treat texts which refer to conflicts over purity issues between Jesus and his critics (most often identified as Pharisees). Again and again, the concern of the Pharisees with purity is dismissed as trivial, or, worse, seen as mean-spirited righteousness; they are accused of being blind hypocrites preoccupied with the minutiae of the law; and purity disputes in general are seen as rather 'stupid'. Any decent person, it is implied, would know that purity laws do not matter very much. To say the obvious: this is the way purity concerns look through modern Western eyes.

But in a purity society, it is not so. In such societies, purity is the core value or paradigm structuring the social world. It becomes embedded in social structures and generates a purity system. Within a purity society, purity issues are neither trivial nor a matter of individual piety. Instead, purity is political.

Second, I have argued that first-century Jewish Palestine was a purity society. Its two centers and foundations were the temple and a particular interpretation of the Torah ${ }^{28}$. The temple's 'holy of holies' was the geographical and cultic center of Israel's purity map, the point of greatest purity, and from it radiated outward concentric circles of decreasing degrees of purity, ending at the borders of 'the holy land'29. The other foundation of the purity system was a way of interpreting the sacred scriptures of Israel which had become increasingly dominant in the centuries since the exile. Its core value was crystallized in a verse from Leviticus: 'You shall be holy as God is holy' (Lv 19:2). Holiness was understood as 'purity', meaning separation from everything unclean. What it meant to be pure was spelled out especially by the purity laws of Leviticus and their elaboration.

Third, of major importance is the way purity and impurity applied to persons and social groups. It got attached to the contrast between righteous and sinners: the pure were the righteous, and the radically impure were sinners (within a purity system, sin 
often becomes a matter of being unclean). Though there was not strictly speaking an inherited caste of 'untouchables ${ }^{30}$ ', as in traditional Hindu society, there were persons whose impurity meant that one could acquire impurity by touching them; hence, there were 'untouchables'. Pure and impure got attached to other primary social polarities: intrinsically to the contrasts between whole and not-whole (the chronically ill and the maimed), Jew and Gentile; and associationally to the contrasts between rich and poor, male and female. As in purity societies generally, these contrasts generated sharp social boundaries.

All of this I have exposited before. What I wish to emphasize here are the connections between purity society, peasant society, and patriarchal society. Two connections are especially striking.

First, to a considerable extent and in a general kind of way, the gradations of the purity system correlated with the descending ladder of peasant society. At the top of the native elites were the ruler (the high priest) and governing class (largely the "chief priests', apparently leading male members of the high priestly families ${ }^{31}$ ). They were the purity elites as well as the political, and economic elites. Politically, the internal affairs of Jewish Palestine during the centuries when the country was under the sovereignty of one foreign empire after another were generally in the hands of the high priest and his council. Economically, the high priestly families were large landowners $^{32}$. This was so despite the Torah's prohibition against priests owning land, which they apparently interpreted not as meaning that they could not own land, but as meaning that they were not allowed to work $\mathrm{it}^{33}$. They could be landlords, but not agricultural laborers. Instead, peasants worked their land, as sharecroppers, renters, or day-laborers. Thus those at the top of the purity system were a traditional aristocracy, a political and economic (as well as religious) elite ${ }^{34}$.

Next came the retainers. Scribes and lawyers would have been advocates of the purity system, lower ranking soldiers probably less so. Among the retainers may have been the Pharisees, A strong strand of contemporary scholarship sees them as a 'purity group' seeking to extend the rules of purity in public life, and emphasizing tithing in particular ${ }^{35}$. If so, their interests and the interest of the high priestly governing class were similar. Wealthy urban merchants were probably committed to purity as well, simply because of their social proximity to the elites. The upper level of the peasant class (farmers who still owned small plots of land) were probably, with respect to purity, marginalized; some may have abided by the purity laws, whereas others did not or could not. Those at the bottom of peasant society - degraded classes and expendables - were generally not only impoverished but also impure. 
Second, the purity system was the ideology of the ruling elites ${ }^{36}$. The claim is made plausible in part by the correlations between purity and class structures, as well as for additional reasons. One of the central functions of ideology is to legitimate the existing order. This the purity system accomplished by locating the temple at its center, thereby legitimating both the temple and the temple elites. Their place in society was divinely sanctioned.

Moreover, the purity system was the result of scribal activity. It was an interpretation of the Torah coming from a scribal class, that is, from a retainer class attached to the elites. The Torah of course contains purity laws. But the decision to make them central and to elaborate them into a system is the product of scribal interpretation. As noted earlier, the 'purity system' resulted from a hermeneutic which made purity the paradigm for interpreting the Torah.

Finally, the income of the temple and the temple elites to some extent depended upon the observance of purity laws by others ${ }^{37}$. Namely, taxation (payment of tithes, which, as stated earlier, amounted to taxes on peasant agricultural production) was a purity issue. Untithed crops were impure, and would not be purchased by the observant. We do not know if the demand for payment of tithe consistently or often involved physical coercion, though it sometimes did. There were, in any case, forms of social and economic coercion. Non-observant Jews were socially ostracized by those committed to purity, and the classification of untithed agricultural produce as impure and therefore not to be bought by the observant amounted to an economic boycott. Moreover, the aristocratic land-owning elite, because of their identity with or connections to the high priestly families, were committed to purity, and it is easy to imagine them refusing to accept produce from their sharecroppers unless the tithes were first paid, thereby effectively requiring payment. Whatever the details, it is clear that the elites had an economic interest in the purity system: it enforced taxation.

Thus I find it persuasive to see the purity system as the ideology of the ruling elites. It provided an ordering of society which established and legitimated the place of the temple elites - the native Jewish aristocracy - at the pinnacle of their social world ${ }^{38}$. This is what I mean when I have described first-century Jewish Palestine as dominated by a politics of purity. Its dominant social vision was a politics of purity in the sense that purity was the ideology of the elites 39 .

We do not know to what degree the ideology of the elites was affirmed by the peasant classes. Were the purity system and the sharp social boundaries engendered by it accepted as norms among peasants ${ }^{40}$ ? Would peasants, for example, have viewed an untouchable as an untouchable? Elites would have, of course. Would peasants have honored the purity system, whatever their ability to observe it and in spite of its nega- 
tive effect upon them? Or would they have felt victimized by it and resentful toward it? Would they have seen the payment of tithes as a sacred obligation, or would they have seen it as an unreasonable and self-serving demand on the part of the elites? The latter is a real possibility, in part because tithes were originally commanded in the Torah because the Levites and priests had no land of their own and therefore had to be supported by others. But now that the high priestly families had become large landowners, their continuing demand that tithes be paid may have seemed unjustified and may have been met with resentment. It is quite possible that the politics of purity and the purity system in which it was embedded were not seen as normative by peasants ${ }^{41}$.

But whether the purity system was accepted by peasants or not, it was the dominant ideology of the social world of Jesus. Within this context, it is significant that conflicts about issues of purity constitute one of the central strands of the Jesus tradition. In this setting, such conflicts had socio-political intentions and consequences. To summarize material I have presented elsewhere, there are five primary categories of texts.

First, there are sayings explicitly referring to purity issues. In general, their effect is to say that purity is not a matter of external condition, but is internal ${ }^{42}$. In the context of modern Western culture, these are 'of course' sayings: true purity is internal, not external. But in the context of a purity society, they are radical and subversive. To say that purity is not a matter of observing external boundaries is to challenge the central organizing structure of the society.

Second, one of the main features of Jesus' activity was an inclusive table fellowship or 'open commensality43'. Commensality was a purity issue. The purity system, with its sharp social boundaries, generated closed commensality. The open commensality of Jesus subverted these boundaries, and embodied a radically inclusive social vision.

Third, purity issues were the central theme of conflicts with the Pharisees, a movement committed to purity in everyday life. Granted, the author of Matthew's gospel wildly accentuated and distorted these disputes, but they do not seem to be simply the creation of the early Christian movement or the evangelists ${ }^{44}$.

Fourth, purity issues are present in some of the healing stories. Jesus is reported to have touched people who were impure and, rather than being defiled himself, the person is 'cleansed' or 'healed ${ }^{45}$ '. Moreover, Jesus' practice of healing outside of institutional authority challenged the system centered in the temple ${ }^{46}$.

Fifth, I have argued that Jesus replaced the 'politics of purity' with a 'politics of compassion'. In contexts where the dominant ideology of his social world spoke of purity as the paradigm for social life, Jesus spoke of compassion ${ }^{47}$. 
In short, the evidence is very strong that Jesus mounted a pointed critique of the purity system of his day. Moreover, it does not seem adequate to suppose that he simply ignored purity. For a religious figure in the context of a purity system to ignore purity is in fact to challenge $\mathrm{it}^{48}$. To put that differently, for an ordinary peasant to have ignored purity may have been without significance; for a figure like Jesus who spoke of the Kingdom of God and who attracted a following, to ignore purity made a strong statement. It was a challenge to a social world organized as a purity system. Purity was not a question of piety, but of society.

\section{PURITY, TEMPLE AND POLITICS}

The perspectives of peasant, patriarchal, and purity society analysis provide a compelling social context for understanding Jesus' action in the temple. Periodically in the history of scholarship, scholars have made the temple act central to their understanding of Jesus. A generation ago, E F Scott did so in a book whose title refers to the temple act: The crisis in the life of Jesus (1952). In our time, Sanders (1985:61-76) uses it as the point of departure for his portrait of Jesus.

The gospel accounts of what Jesus did in the temple (Mk 11:15-17 and Jn 2:13-22) report both an action and a saying, whose function is to interpret the action. For two reasons, it has become routine among scholars to treat the action and the words of interpretation separately. John and Mark both report the action of overturning tables, but report the words of interpretation quite differently ${ }^{49}$. Moreover, both use quotations from the Old Testament to do so, and many scholars systematically suspect the voice of the early movement (rather than the voice of Jesus) whenever scripture is quoted $^{50}$. Thus there is widespread skepticism or suspended judgment about whether the words go back to Jesus, even as there is general confidence that the action does ${ }^{51}$. Accordingly, we shall initially look at the action apart from the words of interpretation.

Jesus overturned the tables of the moneychangers and the seats of those selling sacrificial birds. What did this mean? To say the obvious, interpretation requires a context. Without a context, the meaning of an action (like a saying) ranges from ambiguous (it could mean many things) to opaque (impossible to discern what it means).

Most commonly, it is interpreted as a 'cleansing', reflected in the widespread designation of the event as 'the cleansing of the temple', even though the phrase does rot appear in the story itself. Implicitly, the context is 'purity', with Jesus an advocate of purity: the temple had become defiled, and Jesus wished to purify it. This interpretation sometimes sees the issue as the impropriety of commercial activity in the temple courts, and scmetimes as excessive profiteering involving inflated prices for sacrificial animals and unfair rates of exchange. 
In his review of previous research Sanders persuasively shows the inadequacy of seeing the action as a cleansing or an attempt to purify the temple (Sanders 1985:6168). He then suggests an alternative context for understanding it, namely the context of restoration eschatology: the act of overturning tables symbolized the coming eschatological destruction of the temple and its replacement by another.

Perhaps. But three matters are problematic. The first is Sanders' claim that the act of overturning tables intrinsically points to destruction (see Sanders 1985:70). This seems like a bit of a stretch. The most immediate associations of 'overturning tables' would seem to be a mixture of anger, protest, and indictment. This leads to a second problem. The action seems to imply some kind of indictment, that something was 'wrong'. Yet on Sanders' reading, so far as I can see, there was no indictment of the present temple. The only reason Jesus symbolically enacted the destruction of the temple was because he was operating with an eschatological scenario which said, 'Before the Kingdom of God comes, the present temple will be destroyed'. There was nothing 'wrong' with it which would account for the threat of destruction. Third, for this reading, the meaning of the action had nothing to do with moneychangers or money. Rather, its meaning was extrinsic: it connected to a belief system outside of itself (namely, restoration eschatology), and could be understood only by somebody who knew enough to make that connection.

Thus Sanders sets the temple action in the context of a belief system, where its function was really to 'signal' that set of beliefs. I have no doubt that Jesus had beliefs, and that beliefs matter. But I am skeptical that Jesus had this particular set of beliefs, and that they explain the temple action. The social world sketched in this chapter provides a different context for interpreting the temple action. Rather than being understood within a belief system, it finds its meaning within the social-political context of a peasant, patriarchal, and purity society dominated by temple elites.

As Mark presents the story, the action in the temple was a deliberate act ${ }^{52}$. He describes Jesus going into the temple the day before, looking around at everything, and 'as it was already late', leaving for the night. The other option is to regard it as unplanned, a spontaneous outburst of anger perhaps generated by Jesus' surprise at what was happening in the temple courts ${ }^{53}$. My own hunch is that Jesus had been to Jerusalem before, perhaps many times, and that he knew what was going on there ${ }^{54}$. As a planned action, it had an intention, and is best understood as a 'prophetic act' in the tradition of the classic prophets of Israel.

According to Mark, the next day he returned: Jesus entered the temple and began to drive out those who were selling and those who were buying in the temple, and he overturned the tables of the money-changers and the seats of those who sold doves; and 
he would not allow anyone to carry anything through the temple (Mk 11:15-16). Jesus overturned 'money tables': the tables of money-changers and the seats of sellers of sacrificial birds. Both were providing services to pilgrims. The latter sold to poor people, who were allowed to sacrifice birds rather than more expensive quadrapeds. The money-changers facilitated payment of the temple tax by providing Tyrian shekels (the coinage with which the tax had to be paid) in exchange for other coins. Tyrian shekels were known for their high silver content and careful quality control ${ }^{55}$.

Both the moneychangers and sellers of birds were part of the temple system which stood at the center of the tributary mode of production, drawing money to the Jerusalem elites ${ }^{56}$. Within this context, the action of overturning 'money tables' in the temple had the meaning intrinsic to it as an expression of protest. It was an indictment of what the temple had become: the center of an economically exploitative system dominated by ruling elites and legitimated by an ideology of purity grounded in an interpretation of scripture. It was not an indictment of unscrupulous merchants, but of the elites themselves.

Interestingly, the meaning of the action which flows out of placing it in this context is consistent with the words of interpretation reported by Mark. As already noted, recent scholarship is skeptical that the words go back to Jesus. Behind the question of their authenticity are more questions. Did Jesus ever quote scripture? Did he have the level of scribal awareness one would have to have in order to quote scripture ${ }^{57}$ ? Without seeking to resolve these questions, I would like to suggest what the words of interpretation would mean if they go back to Jesus.

According to Mark, Jesus interpreted the meaning of his act by combining lines from two Old Testament passages: "Is it not written: "My house shall be called a house of prayer for all the nations" (Isa 56:7)? But you have made it "a den of robbers"' (Jr 7:11). Together, they contrasted God's intention for the temple with its present state: the temple was meant to be 'a house of prayer', but it had become 'a den of robbers'.

Both references are important. The line from Isaiah comes from one of the most inclusive visions of temple community in the Hebrew Bible. The temple was to include marginalized groups and outsiders: eunuchs, foreigners, and outcasts (Isa 56:1-8; see Myers 1988:302).

The second phrase, 'den of robbers', echoes a line from Jeremiah's famous temple sermon, in which he indicted the Jerusalem elites of his day 58 . It was they who had acted unjustly, oppressing the helpless (aliens, orphans and widows), even as they also affirmed, in Jeremiah's mocking threefold acclamation, 'This is the temple of the LORD, the temple of the LORD, the temple of the LORD'. As the center of the ruling 
class (aristocracy and priesthood together), the temple had become 'a den of robbers', or 'a cave of violent ones' (as the phrase may also be translated). Thus it was the elites themselves who were indicted as 'robbers' or 'violent ones'. Then, in classic prophetic fashion, Jeremiah followed the indictment with a threat: the sermon ended with the threat that, because of what the temple had become, it would be destroyed.

To move to the words of Jesus as reported by Mark: the allusion to Jeremiah's temple sermon does not suggest the illicit profiteering of merchants or the impropriety of their presence in the temple court, as if everything would have been fine if they had charged less or moved their activity elsewhere. Rather, the indictment was directed at the elites, not at the traders at their tables. As in the days of Jeremiah, the elites had made the temple into a den of robbers and violent ones. The 'You' in 'You have made it a den of robbers' referred not to the money-changers, but to the temple establishment that they and their activity represented. The echo of Jeremiah may also suggest the threat of destruction: because the elites had made the temple into a den of robbers, it would be destroyed 59 . Read in this context, the words of interpretation cohere remarkably well with the action itself. Indeed, this coherence is a reason for seeing the words as historically plausible 60 .

But even without the words of interpretation, the act of overturning 'money tables' in the temple is most plausibly seen as a protest against the temple as the center of an exploitative social-economic system. Action and meaning are intrinsically (rather than merely extrinsically) related ${ }^{61}$. It seems to me that the context generated by the perspectives described in this essay yields a way of reading the story which is more satisfactory than its chief rivals. The temple action was not the invocation of eschatological restoration. Neither was it a cleansing, a purification of the temple, but virtually the opposite. It was anti-purity rather than pro-purity: a protest against the temple as the center of a purity system which was also a system of economic and political oppression.

\section{CONCLUSIONS}

The perspectives provided by patriarchal, peasant, and purity society analysis enable us to see meanings in the message and activity of Jesus that we otherwise would not. Together, they suggest that Jesus walked to the beat of a drummer very different from the dominant ideology of his social world. To say that God's will for human life was compassion rather than purity challenged the domination system of his time, and indeed of most times. Given the perspectives provided by these social models, it is difficult to imagine Jesus' message and activity as primarily concerned about the coming end of all 
things (the eschatological version of Jesus) ${ }^{62}$, or as only concerned about the individual's relationship to God and other individuals (the politically domesticated version of the Jesus tradition).

Thus it seems apparent that Jesus engaged in radical social criticism. A Cynic Jesus might do this. But it is doubtful that Jesus was that individualistic. Moreover, the tone of his message had a sharper edge than a witty mocking of convention. The kind of passion one hears in Jesus' social critique suggests more of the social prophet. It is the same passion I hear in Abraham Heschel's exposition of the passion of the classical prophets of Israel (Heschel 1962). Jesus was not simply concerned with the individual's freedom from the prison of convention, but with a comprehensive vision of life which embraced the social order.

I do not think he was interested in a 'top down' change in the social order which involved taking over or replacing political leadership. Nor do I see him as a reformist, in the sense of seeking to improve or modify the present system ${ }^{63}$. Rather, I see him as having an alternative social vision which, even in his lifetime, may have been embryonically embodied in an alternative community. In his social criticism of the practice and ideology of the dominant classes and in his advocacy of an alternative social vision, we see the politics of Jesus.

Finally, when I say that Jesus was political, I do not mean 'just political', as if we have been mistaken in perceiving him as a religious figure. He was more than political. To use general history of religions categories, he was also (as I have argued elsewhere) an ecstatic, a healer and a wisdom teacher. He was thus to some extent an Elijah-type figure: an ecstatic with paranormal religious experience, a healer, and a social prophet ${ }^{64}$. And he was also an 'enlightened one' who taught a wisdom which both subverted the world of convention and imaged an alternative way of life $^{65}$. Ecstatic, healer, social prophet and wisdom teacher are combined ${ }^{66}$. But he was not less than political. It seems to me that any adequate sketch of Jesus requires a sociopolitical stroke as one of three or four broad strokes. To construe Jesus primarily as an eschatological figure or primarily as a wisdom figure, two of the poles of scholarship in this century, leaves too much of the tradition unassimilated.

\footnotetext{
* This essay is a reworked version of Chapter Five, Jesus in contemporary scholarship, published by Trinity Press International, Valley Forge, Pennsylvania. HTS is granted permission to reprint this article.
}

\section{End Notes}

1 The socio-political dimension of Jesus' message and activity has been a persistent theme of my own work, beginning with my doctoral thesis (1972), 'Conflict as a context for interpreting the 
teaching of Jesus', which was the germ of my Conflict, holiness and politics in the teachings of Jesus (1984). See also my Jesus: A new vision (1987), especially chapters seven through nine, and Meeting Jesus again for the first time (1994b), chapter three.

2 Most recently in the work of Brandon who published a trilogy of books in the 1960s arguing that Jesus was a Zealot sympathizer (see esp Brandon 1967). Scholars now generally do not speak of 'Zealots' in the time of Jesus because of the evidence that 'Zealot' as a term designating a revolutionary Jewish group did come into use until the beginning of the great Jewish revolt against Rome in 66 C E (see Borg 1971:504-512; Horsley 1986:159-192).

3 The erosion of the eschatological consensus in the last two decades is among the reasons for the question of Jesus and politics being reopened.

4 That same social location may also insensitize us to the meaning of community, the role of ritual, and the experience of the sacred, but that is another set of issues.

5 For an introduction to the use of models and perspectives from the social sciences, with a superb bibliography, see Elliott (1993). See also Malina \& Rohrbaugh (1992) and Holmberg (1990).

6 Further description of the pre-industrial agrarian type of society comes from the same volume (see also Kautsky 1982). Within North American Jesus scholarship, Richard Horsley and John Dominic Crossan have been most responsible for introducing the discipline to the illuminating power of peasant-society analysis.

7 The phrase 'tributary mode of production' comes from Gottwald (1993:5), who attributes it to Amin (1980:46-70; see also Gottwald (1992:79-89). Gottwald has been one of the pioneers in applying this mode of analysis to the Old Testament (see esp Gottwald 1979, 1985).

8 See Coote \& Coote (1990:15), who describe the various ways agricultural workers could be related to the land they worked:

A villager might be a cultivating small owner, a cultivator paying fixed rent in cash or kind, a cultivating head of a work team, a sharecropper possessing some 
productive aids like an ox or ass, a sharecropper with only labor to sell but with a regular position on a work team or attached to a parcel of land, a worker with a regular wage paid in cash or kind, a part-time seasonal worker, an indentured servant (debt slave), a slave at forced labor (corvee or statute labor), or a simple slave. Few villagers actually owned their own land.

The volume as a whole makes use of peasant society analysis.

${ }^{9}$ Lenski (1966) reports that a sixteenth century ruler of Japan abolished all other taxes and rents and substituted a land tax of two-thirds of crops, which Lenski sees as typical: it is 'probably the best indication we have of the total take' of the elites in agrarian states (Lenski 1966:267; also cited by Crossan 1991:45-46).

10 If one were to represent visually the economic class structure in such societies, it would not be with the familiar pyramid (large lower class at the bottom, then a smaller middle class, and finally a yet smaller upper class at the apex), but with an oil can with its long narrow needle-like spout (the elites) rising vertically from a broad base (the peasants).

11 For a diagram which very helpfully illuminates the class structure of first-century Jewish Palestine, see Duling (1993:651).

12 See Oakman (1986:72). Oakman (1986:17-91) also provide a dêtailed analysis of economic conditions in first-century Palestine (see also Fiensy 1990).

13 Herod the Great was (to put it mildly) a big spender, undertaking massive building projects both in his own kingdom as well as elsewhere. Though Herod had other sources of income (taxes on trade, land of his own and the production of peasants working it), much of his income had to come from taxes on agriculture (see Oakman 1986:68-71).

14 For a readily accessible account of the tithing system, see Sanders (1992:146-169). The first tithe was to be paid to the Levites, the second tithe was to be consumed by the farmer and his family in Jerusalem, and a third tithe (every third year) given to the poor. In addition, there was an annual temple tax of approximately two days' wages. Sanders argues that the second tithe was 
not really a tax because the farmer himself got to consume it in Jerusalem. This typically involved converting it into money which was then spent in Jerusalem: 'Second tithe counted as festival and holiday money, and it was probably not felt to be a tax' (Sanders 1992:167). For further comment, see next footnote.

15 Sanders argues that many scholars (including Horsley and me) have exaggerated the burden of taxation on Jewish peasants. He notes that many of us have counted the 'second tithe' as a tax, when in fact it was to be consumed by the farmer himself (see previous footnote). In particular, he objects to my estimate (derived from F C Grant) of tithes and taxes adding up to around $35 \%$. Yet on his own accounting, tithes and taxes added up to 28\% (Sanders 1992:166-167), and this does not include the second tithe. True, it might have been a treat for a peasant to spend a tenth of his annual production on holiday in Jerusalem; but the expectation that one would do so was most likely experienced by most peasants as a heavy and probably impossible burden.

16 And thus remarkably close to the two-thirds rate reported by Lenski as the best indication of what is typical in such societies; see note 9 above.

17 Sanders strongly objects to portrayals of the economic situation of peasants in first-century Palestine as particularly oppressive, arguing that their situation was probably not much different from earlier periods and from other places in the empire (see esp Sanders 1992:161-162). He may well be right. But this misses the point (or at least the point I am making). The point is not that Palestine was worse than elsewhere; the point is that this is typical of pre-industrial agrarian societies. See also Sanders (1993:429-448), where he also makes a case that things were not so bad.

18 Mark 12:38-40. For indictments of scribes who were experts in the law ('lawyers'), see Luke $11: 45-52$.

19 The phrase is from Rivkin (1984). That Jesus' death involved not exclusively Roman authority but also cooperation from the Jerusalem elite is widely accepted. 
20 See Gottwald's (1992:86, vol 6) comment: One can locate Jesus within 'the field of political eco-nomy. Jesus led a movement among the heavily taxed and indebted peasantry of Palestine that went on to directly challenge the temple economy and thus the very core of the native tributary mode of production'.

21 Richard Horsley in several books emphasizes the 'social prophet' dimension of Jesus perhaps more than any other contemporary scholar, arguing that Jesus not only indicted elites but also sought to reorganize the life of peasant villages into communities of solidarity. Horsley sets a number of specific traditions within this context. For example, he argues that the mutual forgiveness of debts should be understood quite literally as 'debt forgiveness', and that the saying about love of enemies should be understood to refer to reconciliation of enemies within peasant communities. Though I have learned much from Horsley and find his emphasis on the illuminating power of peasant society analysis completely persuasive, I am not persuaded by some of his more detailed claims. I am not convinced that Jesus sought to re-organize the life of local communities, and I see Jesus as more than a social prophet. It is unclear to me how much Horsley's portrait would be affected by adding the dimensions of wisdom teacher and spirit person/healer.

22 See Schüssler Fiorenza's (1983:106-118) remarks about there being other voices within Judaism. It is worth noting that it is remarkable that there are some biblical and deutero-canonical works about women. Ruth and Judith are especially striking.

23 See Crossan's (1991:8-15) treatment of the politics of sexual honor.

24 This varied somewhat by class. Within the peasant class, women were not as separated from men in public life, largely because of economic necessity (working alongside men in fields, selling produce in markets, etc). See the helpful discussion, with bibliography, by Corley (1993:444459). Corley concludes, however, that this fact should not obscure the great limitations on the lives of peasant women, including gender limitations.

25 There are many Jewish sayings from around or shortly after the time of Jesus which reflect very negative perceptions of (and/or projections upon) women. As Carlston (1980:95-96), has shown, these can be paralleled in Roman and Hellenistic authors of the time. The point is that 
these attitudes are not characteristic of Judaism in particular, as if it were worse than other cultures in this respect. There is no reason to think it was. Rather, such statements and attitudes are generally characteristic of cultures in the first-century Mediterranean world (and, with variations, of most cultures throughout history to the present time).

26 See works cited in footnote 1 above.

27 Within New Testament and Jesus scholarship, the work of anthropologist Mary Douglas has been particularly important, especially her Purity and danger: An analysis of concepts of pollution and taboo (1966). She defines 'purity system' very broadly as an orderly system of classifications, lines, and boundaries, which makes 'purity system' and 'culture' virtually synonymous. I prefer to define 'purity system' and 'purity society' more narrowly: a cultural system of classification that makes explicit use of the language of purity.

28 The phrase 'particular interpretation' is important. I do not see 'purity system' as intrinsic either to the Torah or to Judaism, and I do not equate Judaism itself with 'purity laws' or 'purity system'. Rather (a point to which I return below), 'purity system' was what happened when 'holiness' or 'purity' became the core value (and hence hermeneutical lens) for expounding the Torah, an interpretation which made the purity laws central. There were other hermeneutical lenses through which Judaism's sacred traditions could be seen. For example, a number of popular prophetic movements in the first century made the exodus story central to their understanding of the Torah.

29 Neyrey (1991b:271-304) provides one of the clearest and most accessible expositions of the purity system of Jewish Palestine (see also Neyrey 1986:91-128) See also Countryman (1988:11-65). Countryman focuses his treatment on the relationship between the purity system and sexuality.

30 This needs slight qualification. There were conditions of birth which placed one very low within the purity system. Illegitimacy or a birth defect which left one 'not whole' are examples. 
31 There is some ambiguity about who the 'chief priests' were. 'Chief priests' translates a Greek word which is simply the plural of 'high priest'. Because there there was only one high priest at a time, the Greek plural cannot precisely mean 'high priests'. It could mean 'former high priests', or it could mean priests from 'the high priestly families', namely, aristocratic priestly families from whom high priests were traditionally appointed. For discussion and a preference for the latter meaning, see Sanders (1992:327-328).

32 Many priests (probably the majority) belonged to the poorer classes and were more often among the exploited than they were exploiters.

33 See Sanders $(1992: 77,147)$. I trust that it is not cynical to see class interest at work here: this is the kind of interpretation one would expect from economic elites (I should note that Sanders does not draw this inference).

34 That the high priestly families enjoyed an opulent standard of living is confirmed by recent archaeological excavations of their residences in Jerusalem. They were spacious villas, paved with mosaics, equipped with ritual baths and elaborate bathing installations, and filled with luxury goods (see Avigad 1989:10).

35 The quest for the historical Pharisees is as plagued with uncertainty as the quest for the historical Jesus. See the excellent survey by Saldarini (1992:289-303), and the balanced treatment by Dunn (1988:264-289).

36 See the very helpful discussion of ideology by Myers (1988:17-19). With Myers, I do not see ideas/ideology solely as epiphenomena of the economic base; rather, there is generally a dialectical or reciprocal relation between ideology and socio-economic conditions. The study of how ideology functions socially always includes the question, 'On whose behalf? (Myers 1988:18). Ideology can function to legitimate the social order ('hegemonic ideology'), or to subvert it. My claim is that the purity system, grounded in elite interpretation of the Torah and centered in the temple, was the hegemonic ideology of the first-century Jewish social world. 
37 I say 'to some extent' because both the temple and priesthood had other sources of income. The temple elites (the high priestly families) no doubt drew most of their income from the production of peasants working their land. They (and the rest of the economic elite) also got income from lending money. Though the Torah prohibited interest on loans and also required that debts were to be forgiven every seventh year, ways of getting around both regulations were found: the imposition of fines (not interest) if loans were not repaid on time, and the prosbul (which effectively nullified the sabbatical cancellation of debt). Goodman (1982:422-434) argues that the economic elites instituted these because of their accumulation of excess capital during the first century and their desire to make money off of that capital through loans.

38 Sanders strongly objects to this portrayal of the social world of Jesus, on two grounds. First, he argues that economic conditions in first-century Palestinian Judaism were not worse than elsewhere. Second, he argues that some (and perhaps many) among the elites were good people, and he protests against what seems to him to be a scholarly tendency to equate 'rich' with 'bad', and 'poor' with 'good' (see, e g Sanders 1992:336-340). But this misses the point. The issue is systemic, not individual; it is not about the virtue of individuals, but about the effects of the economic system of a peasant society. Elites as individuals can indeed be good people: devout, responsible, courageous, kind, gentle, generous, charming, intelligent, faithful to spouses, loving to children, loyal to friends, et cetera. To repeat, the issue is not the moral character of elite individuals, but a social system which places over half of the society's wealth into the hands of a few (one to two per cent), with crushing consequences for the many. Finally, I wish to emphasize that all of this is not a fault or characteristic of Judaism. Not only is the same systemic structure the norm in other cultures of the time, but the emphasis upon purity as the ideology of an exploitative system is a particular interpretation of the Jewish tradition: namely, the way the elites interpreted it.

39 The combination of the ideology of purity with the dynamics of a peasant and patriarchal society has been called by Wink (1991 a) 'the domination system' of first-century Jewish Palestine, a system which Wink sees in various forms as the most common type of social organization over the last several thousand years. It is the most persuasive and powerful chapter length treatment of the politics of Jesus known to me. See also Wink (1991b:5-25), where he argues that Jesus was an advocate of active (though non-violent) strategies of political resistance.

40 There is disagreement between two of the most eminent scholars of first-century Judaism as to whether the common people would have observed the purity laws. Sanders (1992:22) thinks they did, Jacob Neusner thinks they did not. 
41 There is considerable evidence of peasant unrest in first-century Jewish Palestine. This seems to have been directed against the Jewish elites as much as it was against the Romans. Indeed, one should not make too great a distinction between Jewish elites and Roman authority, as they were closely related to each other and, from a peasant point of view, were collaborators in the maintenance of what Wink calls 'the domination system'. For a compact listing of incidents of peasant unrest, see Crossan (1991:451-452).

42 These include sayings about the ritual washing of hands (Mk 7:1-5), inside versus outside (Lk 11:37-41 = Mt 23:25-26), what comes out of a person versus what goes into a person (Mk 7:1415 ), true purity is 'of the heart' (Mt 5:8).

43 Jesus' inclusive table fellowship was one of the main themes of my 1972 thesis and 1984 book, and 'open commensality' a main theme of Crossan's book on the historical Jesus.

44 They are found in both Q (Lk 11:37-44, with parallels in Matthew) and Mark, and even once in Thomas. Some scholars, accepting Kloppenborg's analysis of $Q$ into redactional layers (Kloppenborg 1987), see them as inauthentic because they belong to the second layer of $Q$ rather than the first layer. I am skeptical about our ability to sort $\mathrm{Q}$ into layers; moreover, as Kloppenborg himself says, there is no presumption that material found in the second layer of $Q$ is less authentic than material found in the first layer.

45 Examples include the story of the leper in Mark 1:40-45, the hemorrhaging woman in Mark 5:25-34, and the Gerasene demoniac in 5:1-20. Clearly there are symbolic elements in the last story, but it is noteworthy that their effect is to paint a picture of radical impurity: tombs, Gentile territory, pigs. The story is a shattering of purity taboos.

46 A point especially emphasized by Crossan $(1991,1994)$ with his provocative designation of Jesus' healings as 'magic'. Magic is 'religious banditry', analogous to social banditry: a denial of the authority of established religious institutions.

${ }^{47}$ See Borg (1984, 1987, 1994b). 
48 To cite somewhat distant but I think appropriate analogies: for a religious figure in traditional Hindu society to ignore the caste system was in fact to challenge it, just as it would have been for a public figure to ignore the pre-1960 segregation system of the American south.

49 There are also two differences in how they report the action. One is when they locate it in the ministry: John has it at the beginning, and Mark (followed by Matthew and Luke) places it in the last week of Jesus' life. A second difference concerns what Jesus did. Though both agree that Jesus overturned tables, John also has Jesus driving out sheep and cattle. Both the when and what of Mark's report are to be preferred. His placement of the action near the arrest of Jesus (indeed, as its immediate cause) makes historical sense, and Sanders' (1992:87-88) argument that sheep and cattle were unlikely to be in the temple courts is persuasive.

50 In Mark, it is Jesus himself who reportedly quotes the Old Testament in a saying which combines Isaiah 56:7 and Jeremiah 7:11; in John, the quotation is from Psalm 69:9, and it is not attributed to Jesus, but to his disciples who 'remembered' this verse.

51 There are exceptions. Mack (1988:291-292) and Seeley (1993:263-283) argue that it is a Markan creation. Miller (1991:235-252) describes the difficulties involved in reaching a decision about its historicity, though he does not draw a conclusion himself. Nevertheless, that Jesus did something like this is generally accepted. The voting of the Jesus Seminar, a group of scholars who as a whole are on the skeptical side of contemporary scholarhip, is instructive: over twothirds affirmed that Jesus performed an anti-temple act (Funk \& Hoover 1993:97-98).

52 I do not think that Mark gives us an exact report simply because Mark is earlier than John, but I know of no other place to begin than with the earlier account.

53 So, for example, it is presented in the movie The last temptation of Christ. Jesus sees the money tables in the temple, seems surprised by their presence, says, 'What?', and in rage overturns them. If one sees it as a spontaneous act of anger (as some scholars also do), the question of its 'meaning' is muted, whereas seeing it as planned implies a deliberate intentionality.

54 That Jesus had been to Jerusalem before (perhaps many times) is almost certain. He seems to have been a 'religious quester' (how else does one explain his going to the Jordan to hear John the 
Baptizer and then becoming part of John's movement?), and as a Jewish male who was serious about the religious life, it seems intrinsically probable that he had gone on pilgrimage to Jerusalem.

55 Richardson (1992:514-518) notes that the silver content of coins minted in Antioch averaged about $80 \%$, and Tyrian shekels about $90 \%$. Before reading Richardson, I had mistakenly assumed that the issue was 'imageless' coins, and that Tyrian shekels were required because they were free of images. As Richardson points out, they in fact had images of a pagan deity (Melkart) on them. Richardson reads the incident otherwise than I do: he sees the issue as whether the tax was to be paid only once in a person's life, or annually, with Jesus taking the former position. Even so, the issue was still protest against economic aggrandizement by the temple elites, though in a softer form.

56 This is true whether they were actually employees of the temple or high priestly families, or private entrepeneurs. Even if the latter, they were nevertheless in the retainer class, as dependent upon the temple system as the elites themselves.

57 Though I will not argue the point here, my hunch is that the answer to both questions is 'yes'.

58 The temple sermon is in Jeremiah 7:1-15. Another version is in Jeremiah 26:1-6, followed by the story of Jeremiah being seized by the temple authorities and threatened with death. Peasant society awareness is relevant for the reading of this material. It was not all of Judah (peasants and elites alike) who were guilty of these offenses, but the Jerusalem elites in particular.

59 Mark clearly understands the temple action as portending destruction; note how he frames it with the story of the cursing of the fig tree (11:12-14, 20-23). Other traditions make the threat explicit: as noted earlier, the warnings of Jerusalem's coming destruction are threats against Jerusalem as the center of the elites, not against Jerusalem as the center of Judaism.

60 To which I would add one more reason for finding them plausible: prophetic acts in the Old Testament were most often accompanied by words interpreting their significance. On the hypothesis that the temple action was an intentional prophetic act and not an unplanned outburst of anger, it is likely that it was the occasion for a teaching. 
61 There is both continuity and discontinuity between this position and my earlier work (see Borg $1972,1984,1987)$. Both then and now, I saw the temple as the center of the politics of purity, and the temple action as a protest against the politics of purity. However, then I saw the politics of purity (and the temple) as the ideological ground of the national liberation movement; now I see the politics of purity (and the temple) as the ideology of the native ruling elites. Thus my understanding of the temple action (and more generally, of the politics of Jesus) has developed and, in an important respect, changed from my earlier work.

62 Here I use 'eschatological' in the narrow sense argued in Chapter Four of my book Jesus in contemporary scholarship (Borg 1994a). If the word is broadened to include 'utopian', I would be willing to say Jesus was eschatological in that sense - but not if 'utopian' is used in the sense of dreamily irrelevant. I would prefer to speak about the historical relevance of a utopian vision.

63 Myers (1988:85-87) insightfully criticizes the tendency of modern scholars (following Ernst Troeltsch) to see non-reformist movements as politically passive, and then argues that there are 'sectarian' movements which are radically critical of dominant culture, non-reformist, and politically engaged. I understand such a movement, in other language, as an alternative community with an alternative social vision. Myers sees the community behind Mark's gospel as such a group, and his analysis can equally well apply to the Jesus movement during the lifetime of Jesus.

64 Horsley often refers to Jesus as an Elijah-type social prophet, though I am uncertain whether he would emphasize healing and paranormal religious experience as integral to the type.

65 I have developed a picture of Jesus as subversive sage in a number of places (see Borg 1987 , 1994a, 1994b). My use of 'enlightened one' to describe Jesus is meant to suggest that an 'enlightenment experience' lies behind his subversive and alternative wisdom. I think Mitchell (1991) is most likely right: to suppose that Jesus had an enlightenment experience (presumably more than one) seems the most satisfactory explanation of the transformed percepiion which we find in the wisdom teaching of Jesus.

66 It is interesting to speculate about the relationship between enlightenment experience and prophetic passion. The former characteristically relativizes all cultural distinctions by disclosing their artificial character as a 'grid' imposed upon reality. Such an awareness would complement and thereby in a sense temper Jesus' indictments of the elites. Because the distinction between 
elites and peasants is finally relative, even the elites are to be loved (which seems to me a plausible meaning of 'Love your enemies'). Yet there is also a strong affirmation that the oppressive character of the relation between elites and peasants matters. It is reasonable to imagine that the passion of a social prophet and and the wisdom of an enlightened one interact in some such way.

\section{Works consulted}

Amin, S 1980. Class and nation, historically and in the present crisis. Monthly Review, 46-70.

Avigad, N 1989. The Herodian quarter in Jerusalem. Jerusalem: Keter Publishing. Borg, M J 1971. The currency of the term 'Zealots. JTS 22, 504-512.

1972. Conflict as a context for interpreting the teaching of Jesus. D Phil Dissertation, Oxford University.

- 1984. Conflict, holiness and politics in the teachings of Jesus. New York/ Toronto: Edwin Mellen.

1987. Jesus: A new vision. New York: HarperCollins.

1994a. Jesus in contemporary scholarship. Valley Forge: Triniiy Press International.

1994b. Meeting Jesus again for the first time. San Francisco: Harper.

Brandon, S G F 1967. Jesus and the Zealots. New York: Scribner's.

Carlston, C E 1980. Proverbs, maxims, and the historical Jesus. JBL 99, 95-96.

Coote, R B \& Coote, M P 1990. Power, politics, and the making of the Bible. Minneapolis: Fortress.

Corley, K E 1993. Jesus' table practice: Dining with 'tax collectors and sinners', including women, in Lovering, E H (ed), Society of Biblical Literature 1993 Seminar Papers, 444-459. Atlanta: Scholars Press.

Countryman, W 1988. Dirt, greed, and sex. Philadelphia: Fortress.

Crossan, J D 1991. The historical Jesus: The life of a Jewish Mediterranean peasant. New York: Harper.

1994. Jesus: A revolutionary biography. San Francisco: Harper.

Douglas, M 1966. Purity and danger: An analysis of concepts of pollution and taboo. London: Routledge \& Kegan Paul.

Duling, D 1993. Matthew and marginality. HTS 51/2, 358-387.

Dunn, J D G 1988. Pharisees, sinners and Jesus, in Neusner, J et al (ed), The social world of formative Christianity and Judaism, 264-289. Philadelphia: Fortress.

Elliott, J H 1993. What is social-scientific criticism? Minneapolis: Fortress.

Fiensy, D 1990. The land is mine: The social history of Palestine in the Herodian period. New York: Edwin Mellen. 
Funk, R W \& Hoover, R W et al 1993. The five gospels: The search for the authentic words of Jesus. New York: Macmillan.

Goodman, M 1982. The first Jewish Revolt: Social conflict and the problem of debt. Journal of Jewish Studies 33, 422-434.

Gottwald, N K 1992. Sociology of ancient Israel, in Anchor Bible Dictionary 6, 7989.

1979. The tribes of Yahweh. Maryknoll: Orbis.

1985. The Hebrew bible: A socio-literary introduction. Philadelphia: Fortress.

- 1993. Social class as an analytic and hermeneutical category in biblical studies. JBL 112, 3-22.

Holmberg, B 1990. Sociology and the New Testament: An appraisal. Minneapolis: Fortress.

Heschel, A 1962. The prophets. New York: Harper and Row.

Horsley, R H 1986. The Zealots: Their origin, relationships and importance in the Jewish revolt. NT 27, 159-192.

Kautsky, J H 1982. The politics of aristocratic empires. Chapel Hill: University of North Carolina Press.

Kloppenborg, J 1987. The formation of $Q$. Philadelphia: Fortress.

Lenski, G E 1966. Power and privilege: A theory of social stratification. New York: McGraw Hill.

Mack, B 1988. A myth of innocence: Mark and Christian origins. Philadelphia: Fortress.

Malina, B J \& Rohrbaugh, R 1992. Social-science commentary on the synoptic Gospels. Minneapolis: Fortress.

Miller, R 1991. The (a)historicity of Jesus' temple demonstration: A test case in methodology, in Lovering, E H (ed), Society of Biblical Literature 1991 Seminar Papers, 235-252. Atlanta: Scholars Press.

Mitchell, S 1991. The gospel according to Jesus. New York: HarperCollins.

Myers, C 1988. Binding the strong man: A political reading of Mark's story of Jesus. Maryknoll: Orbis Books.

Neyrey, J H 1986. The idea of purity in Mark's gospel. Semeia 35, 91-128

- (ed) 1991a. The social world of Luke-Acts: Models for interpretation. Peabody: Hendrickson.

Neyrey, J H 1991b. The symbolic universe of Luke-Acts: They turn the world upside down, in Neyrey 1991a:271-304.

Oakman, D 1986. Jesus and the economic questions of his day. Lewiston/Queenston: Edwin Mellen. 
Reimarus, H S 1970. On the intention of Jesus and his disciples, in Fragments. Edited by C H Talbert. Translated by R S Fraser. Philadelphia: Fortress. (Lives of Jesus Series.)

Richardson, $P$ 1992. Why turn the tables? Jesus' protest in the temple precincts, in Lovering, E H (ed), Society of Biblical Literature 1992 Seminar Papers, 507-523. Atlanta: Scholars Press.

Rivkin, E 1984. What crucified Jesus. Nashville: Abingdon.

Saldarini, A J 1992. Pharisees, in Anchor Bible Dictionary 5, 289-303.

Sanders, E P 1985. Jesus and Judaism. Philadelphia: Fortress.

1992. Judaism: Practice and belief, 63 BCE - 66 CE. Philadelphia: Trinity Press International.

1993. Jesus in historical context. Theology Today 50, 429-448.

Scott, E F 1952. The crisis in the life of Jesus. New York.

Schüssler Fiorenza, E 1983. In memory of her: Feminist theological reconstruction of Christian origins. New York: Crossroad.

Seeley, D 1993. Jesus' temple act. CBQ 55, 263-283.

Wink, W 1991a. Jesus and the domination system, in Lovering, E H (ed), Society of Biblical Literature 1991 Seminar Papers, 265-286. Atlanta: Scholars Press. 1991b. Neither passivity nor violence: Jesus' 'third way'. Forum 7, 5-25. 